\title{
Yield Prediction of Wheat at Pre-Harvest Stage Using Regression Based Statistical Model for 8 District of Chhattisgarh, India
}

\author{
U.K. Diwan*, H.V. Puranik, G.K. Das and J.L. Chaudhary \\ Department of Agrometeorology, Indira Gandhi Krishi Vishwavidyalaya, \\ Raipur-492012 (CG), India \\ *Corresponding author
}

A B S T R A C T

\begin{tabular}{|c|}
\hline \\
\hline $\begin{array}{l}\text { Regression } \\
\text { technique, Wheat, } \\
\text { Weather, } \\
\text { Temperature, CYF }\end{array}$ \\
\hline Article Info \\
\hline $\begin{array}{l}\text { Accepted: } \\
16 \text { December } 2017 \\
\text { Available Online: } \\
10 \text { January } 2018\end{array}$ \\
\hline
\end{tabular}

Pre harvest crop yield forecast is required for storage, pricing, marketing, import, export etc. Weather is the main factor which affects crop yield. Variability in weather causes the losses in the yield. Use of weather can be done for crop production forecast. Weather plays an important role in crop growth. Therefore model based on weather parameters can be provide reliable forecast in advance for crop yield. In this study, the focus was on the development crop yield forecast (CYF) model through stepwise linear regression technique using weather variables and historic crop yield. The model use, maximum and minimum temperature, rainfall, relative humidity and sunshine hours during crop growing period and long term yield data of wheat crop. Yield prediction was carried out for Wheat (Triticum aestivum) in 8 districts of Chhattisgarh state during 2015-16. The rabi wheat yield and weather data from 1971 to 2012 for 8 districts of Chhattisgarh state were used to develop wheat yield forecast model. From the CYF models it can be inferred that among all the weather variables, temperature (maximum \& minimum) and relative humidity play key role as predictor in all the districts. The models were validated with the actual yield for the 2013 and 2014. Accuracy of these models tested with coefficient of determination $\left(\mathrm{R}^{2}\right)$.

\section{Introduction}

The prediction of product yield in every region in order to planning and policy making future for food providing distribution, pricing and also its import and export is so important since product yield is as result of different processes interaction in plant and these processes are influenced by weather factors, and studying their relationship and product yield are necessary to product-climate models extraction. Since crop yield is the culmination of many temporal plant processes and is affected by various external factors related to soil, weather and technology, parameterization of these factors and investigation of their relationship with yield are essential for crop yield modelling (Baier, 1977; Koocheki et al., 1993). Models based on weather parameters can provide reliable forecast of crop yield in advance of harvest and also forewarning of pests and diseases attack so that suitable plant protection measures could be taken up timely to protect the crops (Agrawal and Mehta, 2007). Rai and Chandrahas (2000) use discriminant function analysis of weather 
variables to develop statistical model for preharvest forecast for yield of rice in Raipur district of Chhattisgarh.

\section{Materials and Methods}

\section{Crop yield data}

Wheat crop yield data collected from Department of Agriculture, Govt. of Chhattisgarh of 1971 to 2012 was used in developing the forecast model and the remaining 2 years from 2013-2014 was used for the validation of the models for each district. The crop yield data for different period for different district were used (presented in Table 1) to develop regression based yield forecast model.

\section{Weather data}

The weekly data of different weather variables viz. Maximum temperature $\left({ }^{0} \mathrm{C}\right)$, minimum temperature $\left({ }^{0} \mathrm{C}\right)$, rainfall $(\mathrm{mm})$, relative humidity (\%) and bright sun shine hours (hours) for the period $45^{\text {th }}-7^{\text {th }}$ standard meteorological weeks for mid stage (F2) and $45^{\text {th }}-12^{\text {th }}$ standard meteorological weeks for pre-harvest stage (F3) were used to get weighted and un-weighted indices for regression analysis in yield prediction of wheat crop. As weather data is not available for all districts, the available four stations weather data (Raipur, Ambikapur, Jagdalpur and Bilaspur) have been used for neighbouring districts (Table 2).

Yield forecast models have been worked out through step-wise regression method using SPSS-16.0 (Statistical Package for the Social Sciences) statistical software on window 7 operating system.

For this purpose, district-level yield was regressed with 42 variables (weighted and unweighted) to get best regression model.
For each weather variable, two indices were worked out.

Un-weighted weather index = Sum (each weekly weather variable)

Weighted weather index = Sum (each weekly variable $\mathrm{x}$ correlation Coefficient between yield and particular week weather variable)

Weather indices denoted as Z; un-weighted indices are 0 and weighted indices are 1. For instance, maximum temperature taken as $1^{\text {st }}$ variable, hence weather index of un-weighted maximum temperature is $\mathrm{Z} 10$ and for weighted Z11. In the same way, other indices were worked out for other weather variables (Table 3). To study the combined effect of weather variables, un-weighted and weighted indices were also computed. For instance, combination of maximum and minimum temperature is obtained by multiplying weekly values of maximum and minimum temperature. For selecting the best regression equation among number of independent variables, stepwise regression procedure was adopted. Statistical Package for Social Science (SPSS) computer software was used for the analysis of data with probability level of $0.05 \%$. A regression model was fitted considering the entered variables obtained from individual stepwise regression analysis to predict the yield of rice and wheat for the subsequent years. The multiple linear stepwise regression analysis has been developed on the basis of examination of coefficients of determination $\left(\mathrm{R}^{2}\right)$, Standard Error (SE) of estimates values resulted from different weather variables.

\section{Results and Discussion}

The regression equations along with standard error (SE), predicted and actual yield were developed for 8 districts of Chhattisgarh state through step-wise regression method. 
Table.1 Wheat crop yield data of different district used to develop yield forecast model

\begin{tabular}{|l|l|c|c|}
\hline S.N. & Districts & Period & $\begin{array}{c}\text { Duration } \\
\text { (Years) }\end{array}$ \\
\hline $\mathbf{1}$ & Raipur, & $1971-2012$ & 42 \\
\hline $\mathbf{2}$ & Jagdalpur & $1980-2012$ & 33 \\
\hline $\mathbf{3}$ & Raigarh & $1983-2012$ & 30 \\
\hline 4 & Dhamtari, Mahasamund, Kanker, Jashpur \& Koria & $1998-2012$ & 15 \\
\hline
\end{tabular}

Table.2 Details of weather data used for different districts of Chhattisgarh state

\begin{tabular}{|l|l|}
\hline Station name & Districts for which weather data used \\
\hline Raipur & Raipur, Mahasamund, Dhamtari and Kanker \\
\hline Ambikapur & Jashpur and Koria \\
\hline Bilaspur & Raigarh \\
\hline Jagdalpur & Bastar \\
\hline
\end{tabular}

Table.3 Notations for un-weighted and weighted indices

\begin{tabular}{|l|l|l|l|l|l|l|l|}
\hline S.no & Weather variable & $\begin{array}{l}\text { Un-weighted } \\
\text { index }\end{array}$ & $\begin{array}{l}\text { Weighted } \\
\text { index }\end{array}$ & $\begin{array}{l}\text { S.N } \\
\mathbf{0}\end{array}$ & Weather variable & $\begin{array}{l}\text { Un-weighted } \\
\text { index }\end{array}$ & $\begin{array}{l}\text { Weighted } \\
\text { index }\end{array}$ \\
\hline $\mathbf{1}$ & Tmax & Z10 & Z11 & 12 & Tmin \& Rainfall & Z230 & Z231 \\
\hline $\mathbf{2}$ & Tmin & Z20 & Z21 & 13 & Tmin \& RH-I & Z240 & Z241 \\
\hline $\mathbf{3}$ & Rainfall & Z30 & Z31 & 14 & Tmin \& RH-II & Z250 & Z251 \\
\hline $\mathbf{4}$ & RH-I & Z40 & Z41 & 15 & Tmin \& SSH & Z260 & Z261 \\
\hline $\mathbf{5}$ & RH-II & Z50 & Z51 & 16 & Rainfall \& RH-I & Z340 & Z341 \\
\hline $\mathbf{6}$ & SSH & Z60 & Z61 & 17 & Rainfall \& RH-II & Z350 & Z351 \\
\hline $\mathbf{7}$ & Tmax \& Tmin & Z120 & Z121 & 18 & Rainfall \& SSH & Z360 & Z361 \\
\hline $\mathbf{8}$ & Tmax \& Rainfall & Z130 & Z131 & 19 & RH-I \& RH-II & Z450 & Z451 \\
\hline $\mathbf{9}$ & Tmax \& RH-I & Z140 & Z141 & 20 & RH-I \& SSH & Z460 & Z461 \\
\hline $\mathbf{1 0}$ & Tmax \& RH-II & Z150 & Z151 & 21 & RH-II \& SSH & Z560 & Z561 \\
\hline $\mathbf{1 1}$ & Tmax \& SSH & Z160 & Z161 & & & & \\
\hline
\end{tabular}

Table.4 Pre-harvest wheat yield prediction for different districts of Chhattisgarh state in crop season Rabi 2015-16

\begin{tabular}{|c|c|c|c|c|c|c|c|c|}
\hline $\begin{array}{l}\text { S. } \\
\text { No }\end{array}$ & District & Equation & $\begin{array}{c}\text { Predicted } \\
\text { yield - 2015-16 }\end{array}$ & $\begin{array}{l}\text { Actual yield } \\
(2014-15)\end{array}$ & $\begin{array}{l}\text { Predicted yield } \\
\quad(2014-15)\end{array}$ & $\begin{array}{l}\% \text { of error } \\
(2014-15)\end{array}$ & $\mathbf{R}^{2}$ & $\begin{array}{l}\text { Std. } \\
\text { Error }\end{array}$ \\
\hline 1. & Jashpur & $\begin{array}{l}Y=2797.72+(0.030 * \mathrm{Z} 451)+ \\
(22.30 * \text { Time })+(25.80 * \mathrm{Z} 11)\end{array}$ & 1442 & 1615 & 1601 & 1 & 0.47 & 134.6 \\
\hline 2 & Koriya & $Y=1322.47+(0.53 * Z 241)$ & 755 & 1120 & 934 & 19 & 0.69 & 120.2 \\
\hline 3 & Raigarh & $\begin{array}{l}Y=1979.92+(13.79 * \text { Time })+ \\
(46.84 * Z 21)+(0.21 * Z 141)\end{array}$ & 1480 & 1640 & 1545 & 6 & 0.39 & 149.8 \\
\hline 4 & Raipur & $\mathrm{Y}=405.98+(22.12 *$ Time $)+(-0.53 * \mathrm{Z} 251)$ & 1513 & 1580 & 1446 & 9 & 0.86 & 170.1 \\
\hline 5 & Dhamtari & $\begin{array}{l}Y=2895.83+(47.19 * \text { Time })+(31.17 * \mathrm{Z} 21) \\
+(0.28 * \mathrm{Z} 141)\end{array}$ & 1437 & 1800 & 1671 & 7 & 0.94 & 84.6 \\
\hline 6 & Kanker & $Y=2132.98+(0.728 * Z 141)$ & 1464 & 1859 & 1743 & 6 & 0.57 & 138.8 \\
\hline 7 & Mahasamund & $Y=10181.4+(0.53 * Z 141)+(51.76 * Z 11)$ & 1181 & 1600 & 1667 & 4 & 0.91 & 154.3 \\
\hline 8 & Bastar & $\begin{array}{l}Y=1037.84+(32.24 * \text { Time })+ \\
(97.64 * Z 21)\end{array}$ & 2207 & 2372 & 2003 & 16 & 0.87 & 145.1 \\
\hline
\end{tabular}


The predicted yield and error based on regression modes are given in the Table 4 . The performance of these regression models were validated with actual wheat yield for the years 2014-15. The accuracy of these crop yield forecast (CYF) models are measured using $\mathrm{R}^{2}$. From the CYF models it can be inferred that among the different variables, the maximum and minimum temperature in combination with relative humidity and time were the most influencing predictors for wheat yield in most of the districts with error ranged between 1 - 19 for the rabi season 2014-15. The developed models have reasonably good $\mathrm{R}^{2}$ i.e. 39 to $94 \%$. Highest $\mathrm{R}^{2}$ value was found in Dhamtari while lowest in Raigarh district. Therefore the model can be used to some extent for predicting the yield in these districts of Chhattisgarh state. The highest error was noticed for Koriya district followed by Bastar district during 2014-15. However, the predictability of regression model was reasonable.

\section{Acknowledgement}

The authors express obligation to Department of Agriculture and biotechnology for providing wheat productivity data. The authors also express their thanks to Department of Agro-meteorology for providing platform for this study as well as reviewers for their constructive comments.

\section{References}

Agrawal, R and Mehta, S.C., 2007. Weather based forecasting of crop yields, pest and diseases- IASRI. Models. J. Ind. Soc. Agril. Statist, 61(2): 255-263.

Baier, W. 1977. Crop weather models and their use in yield assessment. Tech. note. no. 151, WMO, Geneva, 48 pp.

Koocheki, A., Kamali, G. H. and Banaian, M., 1993. Simulation of primary production. The center of agrobiological research and department of theoretical production ecology, Wageningen, Netherlands. Published by World Meteorological Organization. Geneva, July, (Translated in Persian, Tehran).

Rai, T., and Chandrahas, 2000. Use of discriminant function of weather parameters for developing forecast model of rice crop. Publication of IASRI, New Delhi

\section{How to cite this article:}

Diwan, U.K., H.V. Puranik, G.K. Das and Chaudhary, J.L. 2018. Yield Prediction of Wheat at Pre-Harvest Stage Using Regression Based Statistical Model for 8 District of Chhattisgarh, India. Int.J.Curr.Microbiol.App.Sci. 7(01): 2180-2183.

doi: https://doi.org/10.20546/ijcmas.2018.701.262 